\title{
VOLUNTEERING AND COMMUNITY SERVICE
}

\author{
STEVEN RATHGEB SMITH*
}

I

INTRODUCTION

Today, the subject of volunteering and community service is at the heart of contemporary debate among scholars, policymakers, and practitioners on the future of American social policy. This debate is framed, in part, by the language of decline and presents voluntarism as a remedy. For example, many scholars suggest that the capacity of local communities to solve their own problems has been undermined by the growth of the federal government and the professionalization of public services. ${ }^{1}$ To reverse this slide, many scholars and policymakers are calling for an increased reliance on community volunteers and largely volunteer, religious organizations to provide service. More voluntarism, in short, will help American society.

Robert Putnam argues persuasively for more voluntarism for another reason. $^{2}$ He observes that participation in voluntary groups and associations such as the Kiwanis Club, the Girl Scouts, and bowling leagues has fallen significantly in the post-war era. In his view, voluntary organizations with a high degree of interpersonal contact are critical to building a vibrant civil society. Thus, more voluntarism, especially in organizations where a person can build a long-term relationship with others in the community, should be very beneficial for society as a whole. Voluntarism can create social capital - that is, social networks of trust and cooperation-that can then promote greater political involvement and citizen participation in public affairs. The civic infrastructure, broadly defined, will be stronger.

Other scholars supportive of voluntarism worry about threats to individual liberties and freedoms associated with the growth of the state. This perspective

Copyright (C) 2000 by Steven Rathgeb Smith

This comment is also available at http://www.law.duke.edu/journals/62LCPSmith.

* Professor, Daniel J. Evans School of Public Affairs, University of Washington.

1. See generally AmericAn Enterprise institute, MeEting Human NeEds: Toward a New Social Philosophy (Jack Meyer ed., 1982); Peter Berger \& Richard N. Neuhaus, To Empower People: The Role of Mediating Structures in Public Policy (1977); Nathan Glazer, The Limits of Social Policy (1989); John P. KRETZMan \& JOHN L. MCKNight, BuILding COMMUNITIES FROM THE Inside OUT (1993); ROBERT NisBeT, THE QUest FOR Community (1953); William A. Schambra, Is There Civic Life Beyond the Great National Community?, in Civil SOCIETY, DEMOCRACY, AND CIVIC RENEWAL 89-126 (Robert K. Fullinwider ed., 1999).

2. See Robert D. Putnam, Bowling Alone: America's Declining Social Capital, 6 J. Democracy 65, 68 (1995). 
has a long tradition in the United States. Alexis de Tocqueville, writing in the 1830s, was particularly impressed with the penchant of Americans to join voluntary associations, which he regarded as essential to political pluralism and, relatedly, critical bulwarks against state repression and tyranny. ${ }^{3}$ More recently, Peter Berger and Richard Neuhaus echoed this theme in their 1977 book. ${ }^{4}$ They argue that "voluntary associations are important laboratories of innovation" and help "sustain the expression of the rich pluralism of American life." They worry that America is headed in the direction of pluralism and reduced liberty due to the weakening of voluntary associations by the state. ${ }^{6}$

Other scholars worry about a decline in participation in public affairs that threatens democracy and the accountability of government to its citizens. Sidney Verba, Kay Lehman Schlozman, and Henry Brady, in 1995, noted a marked drop in political participation, especially among lower-income individuals, producing a growing inequality in political participation. ${ }^{7}$ Theda Skocpol worries that much of the growth in voluntary political organizations in recent years has been in advocacy organizations with few members who actually participate in the affairs of the organization. ${ }^{8}$ For example, advocacy organizations such as the Sierra Club and National Abortion Rights Action League ("NARAL") are primarily staff-driven organizations where the only involvement of the members is to send money. There is little of the face-to-face interaction characteristic of associations such as the Parent Teacher Association ("PTA") or the Junior League. Skocpol argues that we need to recreate the broad cross-class alliances and associations typical of earlier eras in American politics, although she is doubtful of any immediate turnaround. ${ }^{9}$

II

\section{BACKGROUND}

The solution to the problems of political participation, in the view of Benjamin Barber, is a variety of measures designed to involve citizens more directly in public life. ${ }^{10}$ One key aspect of his reform agenda is national community service. Through participation in voluntary associations, individuals will develop a keener appreciation for civic affairs and understand more completely their obligations to participate in the political process. National

3. See Alexis De Tocqueville, Democracy IN AMericA 198-202 (New American Library 1956) (1835).

4. See BERGER \& NeUHAUs, supra note 1 .

5. Id. at 36 .

6. See id.

7. See generally Sidney Verba ET AL., VOICE AND EQUALITY: CIVIC VOLUNTARISM IN AMERICAN POLITICS (1995).

8. See Theda Skocpol, Advocates Without Members: The Recent Transformation of American Civic Life, in Civic Engagement in AMERICAN Democracy 461-509 (Theda Skocpol \& Morris P. Fiorina eds., 1999).

9. See id. at 504-06.

10. See Benjamin BARber, Strong Democracy: PARticipatory Politics For A New Age 261-311 (1984). 
community service will help prompt-or force-people to understand their obligations as citizens. Following the publication of his book, Barber helped draft the legislation authorizing the AmeriCorps program, the Clinton Administration initiative that provides stipends for individuals interested in working in local voluntary community organizations.

A separate but related argument for voluntarism is its value as a means of individual transformation. For example, City Year is a largely volunteer program that brings together young people from diverse backgrounds to work together on community projects. It is hoped that participation in City Year activities will foster greater sensitivity toward other cultures, offer youths more direction and hope for the future, and provide a learning experience on serious social problems. Other volunteer programs suggest that troubled youths may be able to turn their lives around. For adults, the implicit message of some volunteer programs is less transformational than instrumental: Individuals will meet new people and may even make job contacts or new friends and partners.

In short, voluntarism is offered as just the right tonic for the body politic and individual citizens. Measures to stimulate voluntarism are regarded as essential to countering negative trends in American political and associational life. Central to this agenda of stimulating voluntarism are mandatory and voluntary community service programs in educational institutions. The most typical form of these community service programs is mandatory participation in a volunteer activity in the community, such as serving food at a soup kitchen, building a house for Habitat for Humanity, or helping pick up trash in the school's neighborhood. These community service programs have spread broadly throughout the country in both public and private secondary schools. Some schools now condition graduation on the successful completion of a certain number of community service hours. Many colleges also strongly encourage community service.

\section{III}

\section{RESEARCH}

Despite the widespread interest in voluntarism and measures to encourage it, we actually have relatively few empirical studies evaluating the impact of voluntarism on individuals. Consequently, the three articles by Sally Raskoff and Richard Sundeen, ${ }^{11}$ Rodney Smolla, ${ }^{12}$ and John Wilson and Marc Musick ${ }^{13}$ are especially welcome. Raskoff and Sundeen examine the effects of community service programs on high school students; Smolla focuses on the constitutionality of mandatory community service programs in public schools;

11. See Sally A. Raskoff \& Richard A. Sundeen, Community Service Programs in High Schools, 62 LAW \& CONTEMP. PROBS. 73 (Autumn 1999).

12. See Rodney A. Smolla, The Constitutionality of Mandatory Public School Community Service Programs, 62 LAW \& CONTEMP. PROBS. 113 (Autumn 1999).

13. See John Wilson \& Marc Musick, The Effects of Volunteering on the Volunteer, 62 LAW \& CONTEMP. PROBS. 141 (Autumn 1999). 
and Wilson and Musick investigate the effects of volunteering on volunteers. In the following pages, I will discuss these articles in detail and raise more general points regarding trends in voluntarism and public policy toward voluntary organizations and volunteers.

Raskoff and Sundeen's article provides a fine summary of the literature on mandatory school community service programs. As they note, the existing research on the impact of community service on students is mixed. Some studies indicate that community service promotes personal and social development among students, but others suggest that research to date has not been sufficiently rigorous to reach definitive conclusions. ${ }^{14}$ The connection between community service and greater civic and political participation is also unproven, partly due to the focus of many community service programs on "individualistic, charitable" goals rather than political engagement. ${ }^{15}$

Raskoff and Sundeen's careful research study is an effort to address current deficiencies in the literature and to more solidly test theories and hypotheses on community service. Toward this end, their study had three distinct phases: a mail survey of 385 public and private high schools on their community service programs; personal interviews and mail surveys of community organizations on their attitudes and experiences with high school community service programs; and interviews with 285 students from twenty-two schools on the effects of community service on them.

Their findings are very important and set the agenda for further research. Specifically, they discover wide variation in community service programs offered by high schools and the extent of a school's commitment to community service. Sponsorship does tend to make a difference, however; sectarian high schools are more likely to offer extensive and mandatory community service programs. Community service agencies revealed that they participate in the programs for diverse reasons, but many agencies complained about the implementation of the service programs by the schools. Many agencies observed that it is often difficult to forge ongoing partnerships with the high schools. Teachers are often overloaded, and staff turnover is high. Logistical problems, such as transportation, further undermine an ongoing partnership between school and community agencies. Regarding the impact on students, Raskoff and Sundeen find that most community service programs focus on direct service, such as serving food at a soup kitchen, rather than citizenship. Students also tend to regard direct service as the most satisfying aspect of community service.

To Raskoff and Sundeen, the direct service focus represents a missed opportunity. Without an opportunity for personal reflection and discussion, students have only the direct service experience; thus, they are unlikely to experience the transformational impact envisioned by many proponents of

14. See Raskoff \& Sundeen, supra note 11 , at $80-82$.

15. Id. at 82 (quoting Rahima C. Wade \& David W. Saxe, Community Service-Learning in the Social Studies: Historical Roots, Empirical Evidence, Critical Issues, 24 THEORY \& RES. SOC. EDUC. 331, 346). 
community service. Indeed, even personal growth goals will be difficult to attain if schools do not adequately invest in staff development and program design and monitoring.

The research and conclusions by Raskoff and Sundeen should point the way to more effective, improved community service programs. Their studies also raise larger questions about program implementation and outcomes. Community service programs are a "work in progress": They are relatively new and have expanded rapidly throughout the country, based upon little empirical research and few proven program models. Implementation difficulties are inevitable. As we learn more about the conditions for successful programs, schools will be in a better position to craft effective programs and expand the boundaries of these programs beyond direct service. Whether restructured programs with more explicit attention to citizenship will actually achieve the desired objectives of greater citizen participation remains to be determined. One difficulty faced by researchers is that the effects on citizenship are unlikely to be evident for many years. Therefore, researchers and public school personnel need to recognize the possibility that some outcomes may be impossible to evaluate in the short term.

Rodney Smolla addresses another knotty implementation problem facing community service programs in high schools: their constitutionality. Many parents and students are concerned that mandatory community service interferes with a student's learning and, more fundamentally, his or her individual liberties. As a result, many court cases are underway to test the constitutionality of mandatory community service.

On balance, Smolla finds that mandatory community service is constitutional. In his view, constitutional challenges to mandatory community service can be divided into two generic categories: challenges to the requirement of community service and challenges to the selection criteria of community agencies. He observes that courts are likely to continue to deny both categories of challenges, in part due to the long-standing distinction made in American constitutional law between rights and privileges. Although constitutionally guaranteed rights such as freedom of speech cannot be abridged, many activities, including public schooling, are privileges that are not subject to the same constitutional protections. By sending their children to public schools, parents surrender a certain degree of freedom. Mandatory community service would be constitutionally permissible within that context.

The second category of constitutional challenges-objections to the criteria used to select agencies-is likely to be rejected because most schools, in practice, give students broad discretion to choose a community organization for their service requirement. Only if the choices were greatly restricted or seriously biased would the courts even consider a challenge on these grounds.

Smolla's perceptive, thorough analysis leaves unresolved the question of whether mandatory community service is beneficial to students, the educational process, and the community. To be sure, finding an answer to this question was 
not the focus of his inquiry, but it is also true that the proliferation of mandatory community service programs fits with other trends in public schools to allow less individual discretion for school administrators, including mandatory school uniforms and changes in graduation and suspension policies. These initiatives may well be positive and constitutional, but we also should be mindful of the potential for excess and a skewed balance between community norms and individual liberties.

John Wilson and Marc Musick are interested in the more general subject of volunteering and its impact on the individual volunteer. Their article begins with a comprehensive review of the existing research on the effects of volunteering. One very significant finding from this research is that volunteering early in life, such as in college, appears to be related to greater volunteering later in life. This finding gives support to the proposition that community service programs in high schools might have a stimulative effect on voluntarism over a person's lifetime. Volunteering by teenagers also appears to modestly inhibit antisocial behavior.

In general, Wilson and Musick conclude that volunteering has significant health benefits. Volunteering appears to be related to longer life spans and improved mental health. However, caveats exist. First, health gains from volunteering might be nonlinear: After a certain level of volunteering, the gains might drop off quickly. Second, the type of volunteering is likely to make a big difference in the effects on mental health. Third, the effects of volunteering might be modified by a person's life-cycle stage: Older people, for example, are more likely to achieve health benefits from volunteering than are young people.

While these above findings are significant, they are not conclusive. Some of the studies were conducted on narrow samples or only at a specific point in time. To address these methodological problems, Wilson and Musick use a national data set with longitudinal information. Using this data set, they investigate the relationship between volunteering and depression and conclude that volunteering does enhance mental health. Their results are, nonetheless, suggestive of other research projects, five of which they identify: an analysis of whether volunteering is a sufficient condition for well-being; an examination of the mechanisms linking volunteering and mental health; better differentiation between types of volunteering; better understanding of age differences; and an investigation of the relationship between satisfaction with volunteering and mental health.

Another important aspect of their research is an analysis of the effect of volunteering on a person's work behavior and experience. Their research indicates that volunteering does make a difference: Women with volunteer experience have significantly higher occupational prestige than women without this experience, and the more volunteer experience, the higher the occupational prestige.

Perhaps the most significant finding of Wilson and Musick's research, in its implications for public policy, is that the benefits of volunteering are usually 
unintended consequences of behavior that is motivated not by extrinsic rewards but intrinsic rewards, such as personal satisfaction. This point should at the very least raise a caution flag about various incentives and mandatory requirements to volunteer. The work of Wilson and Musick indicates that these programs, although they may provide a valued service, may not necessarily lead to positive effects on the individual. For example, high school programs that provide incentives for volunteering may not have long-term effects on the individual volunteer, unless the person wanted to volunteer in the first place.

IV

\section{CONCLUSION}

The three articles are important because they provide a sense of what we know and do not know about the effects of volunteering. In general, volunteering does appear to be beneficial for individuals: People can derive personal satisfaction from it, and it can help enhance their mental and physical health and job attainment. Yet these studies suggest that volunteering is not the solution to societal ills envisioned by many proponents of greater volunteering in civic affairs. First, volunteering is not costless. As demonstrated by Raskoff and Sundeen, effective community service programs require a sustained commitment of resources and ongoing staff and volunteer training. ${ }^{16} \quad$ Volunteer programs do not just happen; they require careful planning and concerted attention to program design.

Second, advocates of volunteering as a substitute for government action are likely to be disappointed. Government service programs tend to focus on very disadvantaged groups and individuals-for example, the very poor, the developmentally disabled, and the chronic mentally ill. There programs are often stressful, complicated, and unsuccessful, and, therefore, are not good candidates for voluntarism because the motivation of individuals to participate in voluntary activities is often at variance with the programs. This is not to suggest that some volunteers might not choose to work with the chronic mentally ill, but the research presented by Raskoff and Sundeen and Musick and Wilson suggests that people generally prefer less intense, more psychologically rewarding volunteer positions. The research also suggests that it might be very difficult to provide adequate incentives to get volunteers extensively involved in these types of government programs.

Consistent with this point, faith-based organizations are unlikely to rush to provide government services, even with the new incentives of the Charitable Choice Amendment and the support of a wide variety of politicians. ${ }^{17}$ An

16. This point is also noted in the volunteer management literature. See generally JAMES Q. Wilson, POLITICAL ORGANIZATIONS (1973); Stephen McCurley, Recruiting and Retaining Volunteers, in THE Jossey-BAss HANDBOOK OF NONPROFIT LEADERSHIP AND MANAGEMENT (Robert D. Herman ed., 1994).

17. The Charitable Choice Amendment was passed as part of the landmark welfare legislation of 1996. This Amendment is designed to encourage faith-based organizations, including congregations, to 
individual who belongs to a church is more likely to volunteer, but the types of volunteer activities are likely to be related to intrinsic motivations. One would predict that given the complexity and difficulty of many government programs, as well as the "red tape," a mismatch would exist between the goals of churchbased volunteers and government administrators.

Third, these articles raise important questions about the role of volunteers in building community and social capital. As noted, Robert Putnam argues that social capital-social networks characterized by trust and cooperation-is a positive byproduct of participation in voluntary associations, such as the PTA, sports clubs, or bowling leagues. He argues that the decline in social capital is related to a fall in participation in the kinds of voluntary associations that build social capital. Putnam's work has encouraged many policymakers and scholars to call for public and private programs to stimulate social capital building through the participation in voluntary associations and groups. Yet, these articles suggest that deliberate attempts to create social capital through voluntarism may be very difficult. That is, we know we can prompt at least some people to participate in voluntary associations if we give them specific material rewards, ${ }^{18}$ mandate or encourage their participation in a school setting, ${ }^{19}$ or tap their intrinsic motivation to volunteer, ${ }^{20}$ but the research by Raskoff and Sundeen does not indicate that the students participating in these community service programs develop new interpersonal bonds in the community. Instead, their participation seems to be quite targeted with no new social networks created. To be sure, some of these students may choose to volunteer in organizations later in life, creating new networks. One might also conclude from the research by Raskoff and Sundeen and Wilson and Musick that voluntarism is a deeply personal endeavor; thus, the creation of community-wide networks and increased citizen participation in public affairs may require fundamental shifts in attitudes toward government, politics, and local community.

Overall, then, these three thoughtful articles suggest that voluntarism may indeed be good for people individually. However, whether or not significantly higher levels of voluntarism would be good-or even feasible-for the body politic or civil society remains unresolved. If anything, these articles suggest caution in the drive for voluntarism. Effective programs require careful attention to program design and implementation, and, given the importance of intrinsic motivation to volunteers, we need to be very careful that our expectations for volunteers match their goals and interests.

apply for government funds to help the poor move toward self-sufficiency. See generally Jennifer Moore \& Grant Williams, Good Faith Off to Slow Start, Chron. Philanthropy, Apr. 6, 1999, at 1, 27-30.

18. See MAncur Olson, The Logic of Collective Action (1965); Wilson, supra note 16.

19. See generally Raskoff \& Sundeen, supra note 11.

20. See generally Wilson \& Musick, supra note 13. 